FURTHER DISCOVERY OF ROMAN REMALNS IN LINCOLN.

To the Editor of THE LANCET.

SIR,-Permit me to supplement the letter on the discovery of Roman remains in Lincoln published in THE LANCET of June 14th.

The workmen, a few days ago, whilst extending the digging out of the foundations of the old house at the angle formed by Bailgate and Eastgate preparatory to the building of a new one, came upon a quaint-looking Rijman arch, six or eight feet north-east of the sarcophagus or small chamber in which, as stated in my former letter, the ten urns were discovered. This arch or door-way, which had necessarily to be removed, formed a right angle with the sarcophagus, and was about six feet high and two feet wide Like the large Roman arch at the upper or northern end of Bailgate, it had no keystone, the formation of all the stones in the arch obviating the necessity for one. Leading from the door of the sarcophagus to the arch was a semicircular path made af concrete. This path, after passing through the arch, dipped down two feet and a half to make the floor of a small room five feet square and seven feet higb.

On Thursday morning, the 26th inst., the workmen, whilst in the act of taking down the arch, discovered a large urn, and on clearing away the rubbish out of the room found three or four more urns of large size. The urns previously discovered in the sarcophagus held from two to three quarts of fluid; those recently discovered, before they were damaged would have held as many gallons. They were embedded in lime, had no lids, and all contained ashes of the dead, the ashes being covered over with charcoal. The small room in which these urns were found smelt most offensively, and on washing a fragment of one of the urns, a most disagreeable odour arising from the fragment was complained of. Putting the pieces of one of the urns together, I could see that it was somewhat globular in shape, with a large mouth, the rim of the mouth being neatly and elegantly curved outward to the extent of nearly two inches. The colour of the urn examined is black, and it is a good, although a coarse, specimen of the old Roman ware called "Cpchurch." The fragments of this urn presented an appearance which leads me to believe that the vessel was twice "fired." It is therefore probable that after the dead had been burned in the ordinary way the remains were collected, placed in this large urn, and it and its contents were again subjected to the fire of the crematorium.

Mr. Hibbitt, the intelligent foreman of the works, is of opinion that the arch and the room recently discovered are of much older date than the sarcophagus and apartments previously discovered. Over these old Roman buildings a Norman edifice of some kind bad veen erected, and Mr. Hibbitt pointed out the differences between them. The building of the Romans was "splendid," and the workmen with difficulty pulled down the old walls. The building of the Normans was as different as possible. They made the "faces" of the walls even and smooth but the spaces between the faces they filled up with rubbish of any kind that came to hand, consequently their work fell to pieces when struck by the worknen.

The crematorium and the other buildings devoted to the final disposal of the dead seem to have stood in a north westerly angle of an enclosure or outer courtyard, and this courtyard in all probability belonged to the beautiful villa discovered a year or two ago. The villa stood on one of the finest sites in the city, and was situated only fifty yards directly in front of and southward of the crematorium buildings. Although this place of sepulture may have been owned by successive Roman goveruors, still it does not appear to have been held sufficiently sacred to be isolated from the busy world about it. Not more than twelve or fourteen yards from it eastward was found, firmly and well puddled in the earth, a nine- or ten-gallon water-jar for the use of animals to drink from, and a neat drain was also found to convey away the water overflow of the jar. Still nearer to the sepulture buildings was a well in the centre of a large flat stone, four feet square, and well worn by the feet of those who went thither to draw water. Scattered about were largo square tiles, having one side of the equare curved round, as if intended to hold something. $\Lambda$ packing-needle, of tine brass wire, was found with thread wound around it, und also a handsomely made leaden box, resembling very much the old-fashioned pour-box, with long shaft handle, 'The handlo in this case was wanting, but the tapering socket is there, supported by neat brackets. In still closer proximity to the buildings was the ashbin, among the rubbish of which were found numerous oyster shells and broken pottery, sufficient to demonstrate that breakages occurred in those days as woll as in these. I found the lower part of a llower-pot of Samian ware, having a hole in the bottom for the escape and admission of water in the same way as a flower-pot of the present day. The inverted saucer-like lid for vessels seemed to be very fashionable in those times. The Chelsea people and Orientals made similar lids for sugar-basins. I saw the spout of a jug of Castor ware of the same shape as some of the beautiful Dresden milk-jugs.

I aw, Sir, very truly yours,

Lincoln, June 28th, $1884 . \quad$ WILLIAM O'NEILL, M.D.

\section{"VACCINATION IN THE METROPOLIS."}

To the Editor of THE Lancet.

SIR,-Under the above heading in last Saturday's IAANCET you publish an article stating that the proposal which I made in the Huuse of Commons the other day for the prevention of small-pox in the metropolis was, as you understood it, " to transfer from the boards of guardians to the thirty-nine sanitary authorities the administration of the Vaccination Acts." Permit me to say that I never suggested any such thing. Further on you add that I "demanded a more general use of lymph from the calf." That also is an entire mistake. What I advocated was a slight modification of existing machinery, which might be secured almost without legislation, and which would secure the prompt disinfection and revaccination of infected households as well as the prompt isolation of small-pox patients. The principles of the system I advocated have in Glasgow, where there is no calf ly mph, reduced the death-rate from smallpox to less than one-fiftieth of what it stood at before that system was adopted, and to less than one-twenty-fifth of the present death-rate in the healthiest districts of London. As I showed, they could be adopted here without the slightest dislocation of existing machinery, and probably when the recrudescence of the epidemic next year has sufficiently aroused public indjgnation, the obvious administrative improvements which 1 suggested will be adopted. Till then I must console myself with the reflection that I have done all I conld to avert any needless addition to the thousands of lives which in the metropolis have within the last ten years been deliberately sacrificed at the altar of Small-pox by the High Priest of Red-tape. I am, Sir, yours truly,

House of Commons, July 9th, 1834. CHARLES CAMIERON.

\section{DIAGNOSIS OF SMALL-POX.}

\section{To the Editor of THE LANCET.}

SIR,--It is not very surprising that errors are not infre. quently made in the diagnosis of small-pox, as it is a disease which rarely comes under the observation of general medical practitioners, except during epidemics, and is even then confined to certain localities to a great extent; but with care, and a knowledge of the medical literature on the subject, so far as it can be acquired without much difficulty or expenditure of time, serious errors may be avolded. However, a case illustrative of the grave consequences of a mistake in diagnosis has come under my notice, and I think it is of a nature worth the attention of medical men, especially while small-pox is rife in London. The facts as described by one of the family are these. The father was taken ill and died after a short illness, the immediate cause of death being homorrhage from one of the mucous tracts. There was no apparent small-pox eruption of the usual character, but very extensive petechial or hamorrhagic colouration of the skin, described as "purple," lividity around the eyes, on the forehead, \&c. - in fact, the characters of a severe case of hamorrhagic small-pox. Seemingly the diagnosis was simple purpura, as the family were assured that there was nothing infectious. However, first two of the children, then the wife, and lastly a third member of bis family, were attacked with small-pox, without any apparent history of infection from without, but fortunately in them the disease was of a milder type. If the diagnosis 